\title{
Cold storage possibilities of a larval parasitoid, Venturia canescens (Gravenhorst) (Hymenoptera: Ichneumonidae) ${ }^{1}$
}

\author{
Larva parazitoiti Venturia canescens (Gravenhorst) (Hymenoptera: Ichneumonidae)'in \\ soğuk koşullarda depolanması
}

\author{
Hilal TUNCA ${ }^{2 *}$ Ayşe Nazan YEŞiL ${ }^{2} \quad$ Türkan Feyza ÇALIŞKAN ${ }^{2}$
}

\begin{abstract}
Summary
The effects of cold storage on the biology of the larval parasitoid Venturia canescens were tested. Storage studies were conducted in two stages, pre-adult and adult stage of the larval parasitoid, Venturia canescens (Gravenhorst) (Hymenoptera: Ichneumonidae). Pre-adult stage of parasitoid was stored in last larval stage of the hosts, Ephestia kuehniella Zeller (Lepidoptera: Pyralidae) and Plodia interpunctella Hübner (Lepidoptera: Pyralidae) at $5,10,15^{\circ} \mathrm{C}$ for $1,3,5,7$, and 15 days. Similarly adult parasitoids were stored the same temperatures for honey feeding and non-feeding condition. Storage temperatures, Storage period and host effects on $V$. canescens development were evaluated. The parasitoid did not develop at $5^{\circ} \mathrm{C}$ for 5,7 and 15 day storage period on both hosts. Similarly parasitoid did not develop at $10^{\circ} \mathrm{C}$ for 15 day storage period on the host $P$. interpunctella. Decreasing of temperature and increasing of storage time resulted in increasing in the parasitoid development time, but reducing emergence rate. This reduction of emergence rate was higher in $P$. interpunctella. Longevity and adult dry mass were less affected by low temperature in both hosts., the most suitable temperature for feeding and non-feeding condition on both hosts was found to be at $10^{\circ} \mathrm{C}$ for the adult. The results suggest that $E$. kuehniella could be more suitable host for $V$. canescens.
\end{abstract}

Key words: Venturia canescens; Ephestia kuehniella; Plodia interpunctella; parasitoid, Cold storage

\section{Özet}

Bu çalışmada parazitoit Venturia canescens (Gravenhorst) (Hymenoptera: Ichneumonidae)'in biyolojisi üzerine soğuk depolamanın etkileri çalışılmıştır. Depolama çalışmaları larva parazitoiti $V$. canescens'in ergin öncesi ve ergin döneminde gerçekleştirilmiştir. Parazitoitin ergin öncesi dönemi $5,10,15^{\circ} \mathrm{C}$ sıcaklıklarda ve $1,3,5,7,15$ gün konukçuları Ephestia kuehniella Zeller (Lepidoptera: Pyralidae) ve Plodia interpunctella Hübner (Lepidoptera: Pyralidae)'nın son larva dönemi içinde depolanmıştır. Benzer olarak ergin parazitoitler aynı sıcaklık derecelerinde besinli ve besinsiz koşullarda depolanmıştır. Çalışma sonucunda depolama sıcaklığı, depolama süresi ve konukçu farklıı̆ının $V$. canescensin gelişimini etkilediği belirlenmiştir. Parazitoitin iki konukçuda da $5^{\circ} C^{\prime}$ de 5,7 ve 15 gün depolama sürelerinde gelişim göstermediği belirlenmiştir. Benzer olarak parazitoitin konukçu $P$. interpunctella üzerinde $10^{\circ} \mathrm{C}^{\prime}$ de 15 gün depolanmasıyla da gelişim gösteremediği bulunmuştur. Depolama sıcaklığının düşmesi ve depolama süresinin artması parazitoitin gelişme süresini artııırken, çıkış oranını azaltmışıı. Çıkış oranındaki azalma konukçu $P$. interpunctella üzerinde daha fazladır. Yaşam süresi ve ergin ağırığı iki konukçuda da düşük sıcaklıkdan daha az etkilenmiş̧ir. Ergin parazitoiter için hem besinli hem de besinsiz ortamda ve heriki konukçuda en uygun sıcaklık derecesinin $10^{\circ} \mathrm{C}$ olduğu belirlenmiştir. Sonuçlar, depolama çalışmalarında $V$. canescens için $E$. kuehniella'nın daha uygun bir konukçu olduğunu göstermektedir.

Anahtar sözcükler: Venturia canescens; Ephestia kuehniella; Plodia interpunctella; parazitoit, soğuk depolama

\footnotetext{
${ }^{1}$ Bu çalışma TÜBITAK-BIDEB tarafından desteklenmiştir

${ }^{2}$ Ankara Üniversitesi Ziraat Fakültesi Bitki Koruma Bölümü,06110,Ankara

* Sorumlu yazar (Corresponding author) e-mail: htunca@ankara.edu.tr

Alınış (Received): 13.06.2013 Kabul ediliş (Accepted): 21.11.2013
} 


\section{Introduction}

In recent years, biological control is more ordinarily utilized, especially in ecologically based integrated pest management. Parasitoids are extensively used in biological control programs. Mass rearing of parasitoids has been regarded a necessity for biological control againts pests, particularly biological control applications supported on inundative releases (van Lenteren \&Tommasini, 2002).

The main difficulty of the prosperous execution of mass releases is the capability to rear high numbers of parasitoids when requirement is maximum and cost of producing natural enemies in high numbers for augmentative release at the suitable time (Glenister \& Hoffmann, 1998). Pesticides have a long shelf life, however many beneficial insects used in biological control have a comparatively short longevity, so that beneficial insects should be reared for a short time before they are utilized. The improvement of an effective method of storage can decrease the cost of biological control by spreading the long term (McDonald \& Kok, 1990; Venkatesan et al., 2000).

Cold storage has pointed to be an important method for increasing the beneficial insects shelf-life . Storage at low temperature permits synchronized field releases of beneficial insects during the appropriate stage of a suitable host insect (McDonald \& Kok, 1990; Venkatesan et al., 2000). Storage at low temperature can allow a more cost-effective insect production (Glenister \& Hoffmann, 1998). It may also preserve natural enemies when not instantly needed. Commercial producers may supply exceptionnally large numbers during peak demand periods (Pitcher et al., 2002).

Low-temperature storage of the beneficial insect is commonly applied. Permissiveness to low temperature is a very flexible trait determined by a broad range of factors (biotic and abiotic) experienced before, during, or after cold exposure (Colinet \& Boivin, 2011). Various factors may affect the cold storage studies. Storage period, this is one of the most important factors for this research. For this reason, cold storage studies are divided into two parts such as short term storage and long term storage. Leopold (1998) defined short-term storage as less than 1 month and anything over that as long-term storage. In this study, short-term storage was used for $V$. canescens.

Solitary, koinobiont larval parasitoid Venturia canescens (Gravenhorst) (Hymenoptera: Ichneumonidae), is an endoparasitoid of several lepidopterous. Its host spectrum contains many moth species including Ephestia cautella Wk, Ephestia elutella Hübn, Ephestia kuehniella Zell, Nemapagon granella Linn, Pyralis farinalis Linn, Aphomia sociella Linn, Esperia sulphurella Fabr, Peralipsa gularis Zell, Plodia interpunctella Hübn, Prays citri Mill, Homeosoma neubella Hübn, Vitula edmanse Pack, Clepsis peritana Clem, Galleria mellonella Linn, Achroia grisella Fabr, Corcyra cephelonica Staint, Ephestia figuliella Greg, Paramleyosis transitella Wk, Pexicopia malvella Hübn, Phtromaea operculella Zell. (Frilli, 1965; Salt, 1975, 1976). Both arrhenotokous and thelytokous reproduction can be seen in this parasitoid (Beukeboom et al., 1999). Schneider et al. (2002) reported that arhenotokous and thelytokous parasitoids have different geographical distribution. Particularly; in arrhenotokous parasitoids, there are different ecological requirements. Thelytokous parasitoids is spreading to larger areas. This situation is explained by two reasons. First, most of these studies made use of a few commonly splited laboratory strains. The second reason is that several of the hosts of Venturia are stored product pests and the strains were generally gotten from bakeries or granaries (Press et al., 1982; Cline et al.,1983; Driessen et al., 1995; Harvey \& Vet, 1997; Bonsall \& Hassell, 1998). These places supply a relatively stable environment and several pyralid hosts (Freeman, 1980; Goater, 1986; Harvey \& Thomson, 1995). Under such conditions arrhenotokous populations are likely to be quickly surmount by thelykous ones. Regular shipments of flour between mills and bakeries can expand a thelytokous strain quickly over a large area once it has occured. So bakeries may supply as source populations from which thelytokous parasitoids can get in the environment (Schneider et al. 2002). These parasitoids have a wide tolerance about changing in abiotic factors and differences in host distribution and specificity. Additionally, thelytoky strain of this parasitoid may have different biology (Beling, 1932; Gade \& Parker, 1997; Jokela et al., 1997; Vrijenhoek, 1999; Beukeboom \& Pijnacker, 2000; Barke et al., 2005). 
Thelytokous parasitoid Venturia canescens is occurred in different storages of Turkey. In this study the parasitoids ,obtained from grain storages of Ankara province were used. There are many studies on the biology and effectiveness of V. canescens. (Kansu \& Uğur, 1985; Özkan \& Gürkan, 2002; Özkan et al., 2003, Özkan, 2004; Gökçek, 2005; Boz, 2006; Ozkan, 2007; Sahin \& Ozkan, 2007; Boz \& Gülel, 2012).However, there is no record on the storage of the thelytoky strain of this parasitoid in Turkey.. The aim of this study is to find out the suitable cold storage conditions for mass rearing of $V$. canescens.

\section{Materials and methods}

\section{Insect culture}

Both hosts Ephestia kuehniella Zeller (Lepidoptera: Pyralidae), Plodia interpunctella Hübner (Lepidoptera: Pyralidae) and parasitoid Venturia canescens Grav. (Hymenoptera: Ichneumonidae) were obtained from the laboratory at Ankara University, Faculty of Agriculture, Department Plant Protection. The host Ephestia kuehniella Zeller (Lepidoptera: Pyralidae) was reared at $25 \pm 1^{\circ} \mathrm{C}, 60-70 \%$ R.H., $16 \mathrm{~h}$ light and $8 \mathrm{~h}$ dark condition. Culturing was undertaken using clear plastic containers $(27 \times 37 \times 7 \mathrm{~cm})$ on a 2:1 mixture of wheat flour and rough wheat bran containing approximately $400 \mathrm{~g}$ food, which was sterilized at $60^{\circ} \mathrm{C}$ for 3 days, and 5.000 host eggs. E. kuehniella eggs were homogeneously dispersed in this food (Bulut \& Kılınçer, 1987).

The host Plodia interpunctella Hübner (Lepidoptera: Pyralidae) was reared in laboratory condition $\left(25 \pm 1^{\circ} \mathrm{C}, 60-70 \%\right.$ R.H., $16 \mathrm{~h}$ light and $8 \mathrm{~h}$ dark). In the rearing of $P$. interpunctella, wheat bran, corn flour, dry yeast, honey, milk powder, and glycerin were mixed in a ratio of 2:1:0.25:0.50:0.25:0.25, respectively. Before using the mixed preparation, it was kept in an incubator. Sterilized plastic breeding containers with $15 \times 20 \times 7.5 \mathrm{~cm}$ in size were filled with $300 \mathrm{~g}$ of sterilized food and over this nearly $400 \geq 1$-day-old $P$. interpunctella eggs were homogeneously dispersed using a soft tip brush (Ozkan, 2006).

The parasitoid $V$. canescens was cultured on mature larvae of $E$. kuehniella in plastic containers under laboratory condition $\left(25 \pm 1^{\circ} \mathrm{C}, 60-70 \%\right.$ R.H., $16 \mathrm{~h}$ light and $8 \mathrm{~h}$ dark $)$. In order to rear the parasitoid, 10 (4- to 5-day-old) adult parasitoids which had been daily fed with pure honey were transferred into the container including approximately $250 \mathrm{~g}$ sterilized food and approximately 300 twenty nine day-old mature larvae. After $24 \mathrm{~h}$ parasitization, parasitoids were removed from the container in order to prevent probable superparasitism (Ozkan, 1999).

\section{Cold storage treatments}

Cold storage treatments were carried out for pre-adult and adult stage of $V$. canescens. For preadult stage, fifth instars of $E$. kuehniella and $P$. interpunctella were singly parasitized by $V$. canescens. Following a successful oviposition, the parasitoid preens and transfers a new egg to the tip of her ovipositor via a characteristic flexing motion of the abdomen (the 'cocking' motion described by Rogers, 1972). Singly parasitized larvae were transferred to plastic boxes containing enough fresh food. The parasitized larvae were fed with food for two hours.

Treatments consisted of combinations of three temperature levels $\left(5,10,15^{\circ} \mathrm{C}\right)$ with five cold storage times $(1,3,5,7$, and 15 days). There was also a control group (without cold storage). The control group was kept at standard rearing conditions $\left(25 \pm 1^{\circ} \mathrm{C}, 60-70 \%\right.$ R.H., $16 \mathrm{~h}$ light and $8 \mathrm{~h}$ dark). Once the storage period was over, each treated group was transferred to the laboratory at standard condition. The effect of cold storage on the quality of the parasitoid was evaluated by measuring the following parameters in each replicate: development time, emergence ratio, adult longevity and adult dry mass. In order to determine parasitoid dry mass $(\mathrm{mg})$, they were frozen upon emergence and later oven-dried for 5 days at $60^{\circ} \mathrm{C}$ (Harvey et al., 1993).

To evaluate the effect of cold treatments on the adult parasitoid, the parasitized larvae were incubated at the rearing condition until adult emergence. The newly $(0-6 \mathrm{~h})$ emerged $V$. canescens adults were put into glass tube $(1.5 \times 11 \mathrm{~cm})$ individually. The glass tube containing adult parasitoid was stored in cold incubator at 5,10 and $15^{\circ} \mathrm{C}$. The control group was kept at standard rearing conditions $\left(25 \pm 1^{\circ} \mathrm{C}\right.$, 
60-70\% R.H., $16 \mathrm{~h}$ light and $8 \mathrm{~h}$ dark). Parasitoid adults were stored at two different conditions (with food and without food). With food condition, parasitoids were fed on diluted honey solution (\%10) at two day interval during storage.

\section{Statistical analysis}

Development time, emergence ratio, adult longevity and adult dry mass data were analyzed with one-way analyses of variance (ANOVA). Means were separated by using Duncan's Multiple Range Test and t-test was used for comparing two means. Percentage data were arcsine transformed before analysis. All statistical analyses were carried out using MINITAB computer software Release 14 (McKenzie \& Goldman 2005). MSTAT C was used for variance between treatment means. All the analyses were carried out at the $5 \%$ significance level.

\section{Results}

\section{Cold storage of pre-adult stage}

The effects of cold storage on pre-adult stage are presented in Table 1. Emergence of $V$. canescens occurred in all treatments, except for those parasitized $E$. kuehniella larvae stored 5, 7, 15 days at $5^{\circ} \mathrm{C}$. The development time $(\mathrm{df}=2, \mathrm{~F}=49.12, \mathrm{P}=0.000)$, longevity $(\mathrm{df}=2, \mathrm{~F}=0.79, \mathrm{P}=0.458)$ and dry mass $(\mathrm{df}=2, \mathrm{~F}=1.71, \mathrm{P}=0.186)$ of parasitoids did not affect by the storage 1 day at $5^{\circ} \mathrm{C}$. However, development time of the parasitoid was significantly affected by the storage 3 day at $5^{\circ} \mathrm{C}$. Storage of parasitized larvae for 1 and 3 days at $5{ }^{\circ} \mathrm{C}$ resulted in significantly lower adult emergence rates than that of the control $(\mathrm{df}=2, \mathrm{~F}=14.45, \mathrm{P}=0.005)$.

Development time of the parasitoid significantly increased with extending the storage period at $10^{\circ} \mathrm{C}(\mathrm{df}=5, \mathrm{~F}=712.01, \mathrm{P}=0.000)$ while longevity of parasitoid was not affected by 1-, 3-, 5-, 7-, and 15-day of storage at this temperature $(\mathrm{df}=5, \mathrm{~F}=1.44, \mathrm{P}=0.210)$. There was significant difference in dry mass of parasitoid only between 7-day cold storage at $10^{\circ} \mathrm{C}$ and control group ( $d f=5, F=3.00, P=0.012$ ). Emergence ratio of parasitoid in all storage periods decreased compared to control $(\mathrm{df}=5, \mathrm{~F}=5.99$, $\mathrm{P}=0.005$ ). Development time of parasitoid varied significantly among storage period at $15^{\circ} \mathrm{C}$, except for 1 day $(\mathrm{df}=5, \mathrm{~F}=655.34, \mathrm{P}=0.000)$. Longevity of adult parasitoid was positively affected after 1-, 3-, 5-, 7-, and 15 - day storage at $15^{\circ} \mathrm{C}(\mathrm{df}=5, \mathrm{~F}=17.20, \mathrm{P}=0.000)$. There was no significant differences in dry mass between 1-, 3-, 5-, 7- and 15-day storage at $15^{\circ} \mathrm{C}$ and control group ( $\mathrm{df}=5, \mathrm{~F}=3.73, \mathrm{P}=0.003$ ). Similarly, there was no significant differences in emergence ratio between control group and 1-, 3-, 5- and 7-day storage at $15^{\circ} \mathrm{C}$, except for 15 -day storage $(\mathrm{df}=5, \mathrm{~F}=3.21, \mathrm{P}=0.04)$.

As in the host E. kuehniella, there was no parasitoid emergence from parasitized $P$. interpunctella larvae after 5-, 7-, 15- day storage at $5^{\circ} \mathrm{C}$. Development time of parasitoid was significantly affected after storage for 1 and 3 days at $5^{\circ} \mathrm{C}(\mathrm{df}=2, \mathrm{~F}=65.71, \mathrm{P}=0.000)$. Similarly, longevity, dry mass and emergence ratio of parasitoid were significantly affected by 1 - and 3 - day storage at $5^{\circ} \mathrm{C}(\mathrm{df}=2, \mathrm{~F}=18.83, \mathrm{P}=0.000$; $\mathrm{df}=2, \mathrm{~F}=68.84, \mathrm{P}=0.000 ; \mathrm{df}=2, \mathrm{~F}=18.99, \mathrm{P}=0.003$ ). There was no parasitoid emergence from parasitized $P$. interpunctella larvae after $15-$ day storage at $10^{\circ} \mathrm{C}$. Development time of parasitoid was significantly decreased with increasing storage periods at $10^{\circ} \mathrm{C}(\mathrm{df}=4, \mathrm{~F}=88.54, \mathrm{P}=0.000)$. Longevity of parasitoid was significantly reduced after $5-, 7$ - day storage at $10^{\circ} \mathrm{C}(\mathrm{df}=4, \mathrm{~F}=35.34, \mathrm{P}=0.000)$. Significant differences in dry mass and emergence ratio of $\mathrm{F} 1$ progeny were found between storage treatments and the control group ( $\mathrm{df}=4, \mathrm{~F}=21.88, \mathrm{P}=0.000 ; \mathrm{df}=4, \mathrm{~F}=25.51, \mathrm{P}=0.000$ ). Development time of the parasitoid was significantly affected by $3-, 5-, 7$ - and 15 - day storage at $15{ }^{\circ} \mathrm{C}(\mathrm{df}=5, \mathrm{~F}=357.90, \mathrm{P}=0.000)$. Longevity and dry mass of parasitoid were significantly reduced after $5-, 7$ - and 15 - day storage at $15^{\circ} \mathrm{C}(\mathrm{df}=5, \mathrm{~F}=15.77$, $P=0.000 ; d f=5, F=9.40, P=0.000$ ). Emergence ratio of parasitoid in all storage periods, except for 1 - and 3-day storage decreased compared to control ( $d f=5, F=5.80, P=0.000)$. 


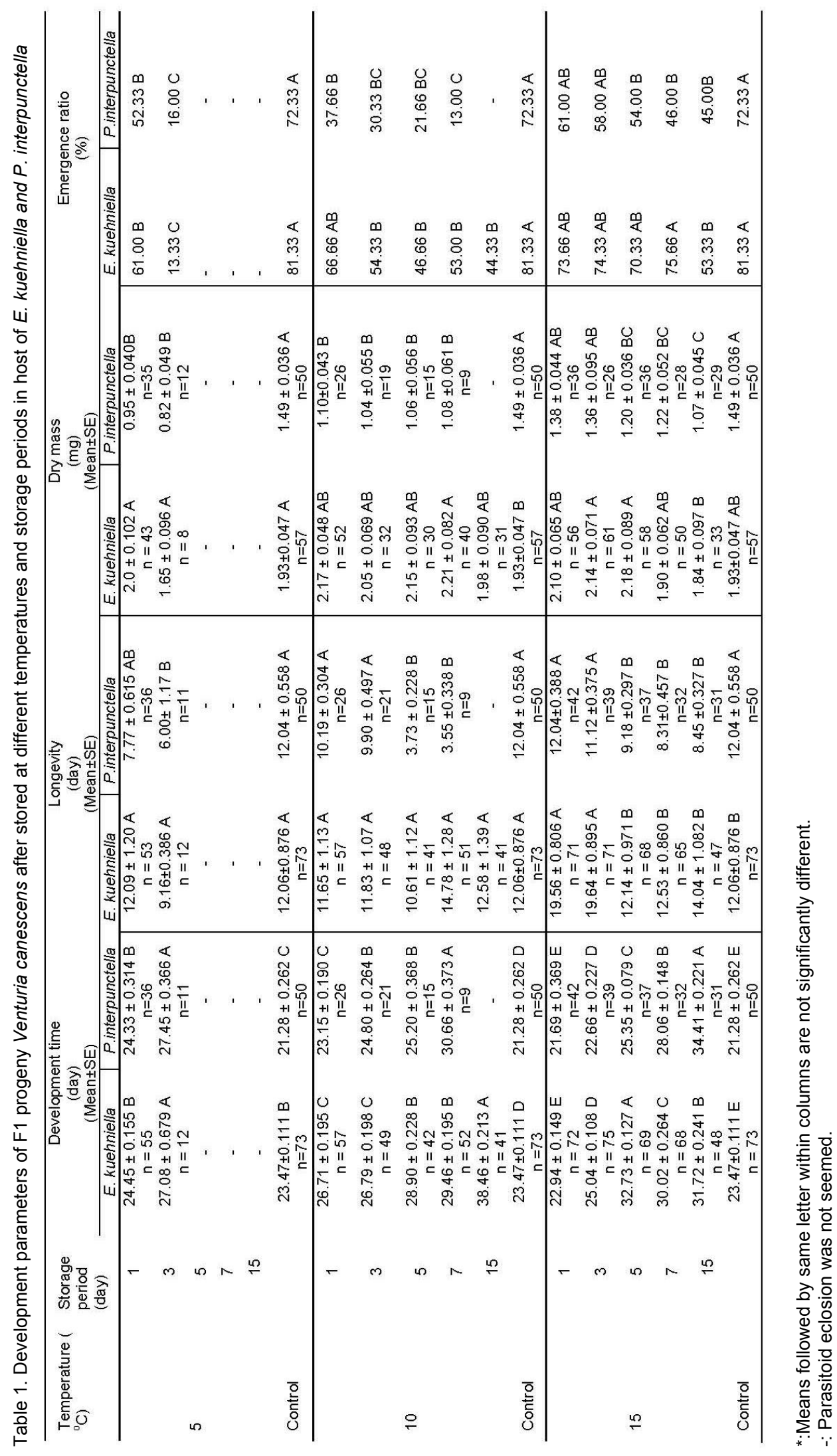




\section{Cold storage of adult stage}

Temperature during storage significantly affected the longevity of $V$. canescens reared on $E$. kuehniella and $P$. interpunctella with food and without food condition $(\mathrm{df}=3, \mathrm{~F}=23.46, \mathrm{P}=0.000$; $\mathrm{df}=3$, $\mathrm{F}=233.42, \mathrm{P}=0.000 ; \mathrm{df}=3, \mathrm{~F}=19.71, \mathrm{P}=0.000 ; \mathrm{df}=3, \mathrm{~F}=191.99, \mathrm{P}=0.000$, respectively) (Table 2 and Table $3)$. The longevity of $V$. canescens significantly decreased in food condition at $5{ }^{\circ} \mathrm{C}$. However, parasitoid lived longer compared to control group in without food condition at $5{ }^{\circ} \mathrm{C}$. The highest mean longevity was obtained for $V$. canescens stored at $10^{\circ} \mathrm{C}$ on both hosts. Mean longevity of parasitoids stored at 10 and $15^{\circ} \mathrm{C}$ with food condition was longer than that without food condition on $E$. kuehniella and $P$. interpunctella ( $\mathrm{df}=47, \mathrm{~T}=5.46, \mathrm{P}=0.000 ; \mathrm{df}=58, \mathrm{~T}=9.49, \mathrm{P}=0.000 ; \mathrm{df}=57, \mathrm{~T}=2.84, \mathrm{P}=0.006 ; \mathrm{df}=58$, $\mathrm{T}=6.90, \mathrm{P}=0.000$, respectively) except for $5{ }^{\circ} \mathrm{C}(\mathrm{df}=58, \mathrm{~T}=0.31, \mathrm{P}=0.759$; $\mathrm{df}=58, \mathrm{~T}=1.84, \mathrm{P}=0.071$, respectively). Similar result was obtained for control group on $E$. kuehniella and $P$. interpunctella ( $\mathrm{df}=59$, $\mathrm{T}=9.7, \mathrm{P}=0.000 ; \mathrm{df}=58, \mathrm{~T}=14.95, \mathrm{P}=0.000$, respectively) (Table 2; Table 3).

Table 2. Longevity of Venturia canescens stored at different temperature in the host Ephestia kuehniella

\begin{tabular}{ccc}
\hline Temperature $\left({ }^{\circ} \mathrm{C}\right)$ & \multicolumn{3}{c}{$\begin{array}{c}\text { Longevity } \\
\text { (Mean } \pm \text { SE) }\end{array}$} \\
\cline { 2 - 3 } 5 & With food & Without food \\
\hline 10 & $8.067 \pm 0.745 \mathrm{Da}$ & $7.833 \pm 0.136 \mathrm{Ba}$ \\
$\mathrm{n}=30$ & $\mathrm{n}=30$ \\
& $22.263 \pm 1.914 \mathrm{Aa}$ & $13.400 \pm 0.466 \mathrm{Ab}$ \\
15 & $18.600 \pm 1.168 \mathrm{Ba}$ & $\mathrm{n}=30$ \\
& $\mathrm{n}=30$ & $6.433 \pm 0.422 \mathrm{Bb}$ \\
Control & $12.880 \pm 1.447 \mathrm{Ca}$ & $\mathrm{n}=30$ \\
& $\mathrm{n}=25$ & $1.722 \pm 0.162 \mathrm{Cb}$ \\
& & $\mathrm{n}=36$
\end{tabular}

*:Means followed by same letter with lower-case letters in the rows and capital letters in the columns do not differ statistically

Table 3. Longevity of Venturia canescens stored at different temperature in the host Plodia interpunctella

\begin{tabular}{|c|c|c|}
\hline \multirow[t]{2}{*}{ Temperature $\left({ }^{\circ} \mathrm{C}\right)$} & \multicolumn{2}{|c|}{$\begin{array}{l}\text { Longevity } \\
\text { (Mean } \pm S E)\end{array}$} \\
\hline & With food & Without food \\
\hline 5 & $\begin{array}{c}7.767 \pm 0.354 \mathrm{Ca} \\
n=30\end{array}$ & $\begin{array}{c}6.866 \pm 0.338 \mathrm{Ba} \\
n=30\end{array}$ \\
\hline 10 & $\begin{array}{c}15.103 \pm 0.904 \mathrm{Aa} \\
\mathrm{n}=29\end{array}$ & $\begin{array}{c}12.300 \pm 0.421 \mathrm{Ab} \\
\mathrm{n}=30\end{array}$ \\
\hline 15 & $\begin{array}{c}11.467 \pm 0.731 \mathrm{Ba} \\
\mathrm{n}=30\end{array}$ & $\begin{array}{c}6.000 \pm 0.303 \mathrm{Bb} \\
\mathrm{n}=30\end{array}$ \\
\hline Control & $\begin{array}{c}13.833 \pm 0.803 \mathrm{ABa} \\
\mathrm{n}=30\end{array}$ & $\begin{array}{c}1.733 \pm 0.095 \mathrm{Cb} \\
\mathrm{n}=30\end{array}$ \\
\hline
\end{tabular}

*: Means followed by same letter with lower-case letters in the rows and capital letters in the columns do not differ statistically

\section{Discussion}

In this study the larval parasitoid $V$. canescens was stored in the short term. Cold storage tolerance of $V$. canescens showed differences depending on temperature, storage period and host. Bigler (1994) reported that cold storage resistant/tolerance of insects may be influenced by a range of internal such as mass and body reserves, life-history strategy, nutrition, mode of reproduction, age/stage, dormancy status, gender and external factors like temperature, duration of exposure, acclimatization, developmental temperature, constant or fluctuating cold exposure, combined cold exposure, humidity, photoperiod, chemicals, oxygen concentration, handling. Cold storage of $V$. canescens at $5{ }^{\circ} \mathrm{C}$, for more than 3 days on both hosts, had detrimental effects on development. Parasitoid completed their development at other 
tested temperatures, except for at except for 15 days at $10{ }^{\circ} \mathrm{C}$ in the host $P$. interpunctella. Colinet \& Boivin (2011) reported that for the purpose of augment shelf-life of beneficial insects benefit from the cold storage, such as temperature ranging from 0 to $15^{\circ} \mathrm{C}$. But these moderately low temperatures have a detrimental effect on lifespan of beneficials (Leopold et al., 1998; van Lenteren \& Tommasini, 2002). The lower the storage temperature resulted the higher the mortality in many studies. (Ballal et al., 1989; Venkatesan et al., 2000 Rundle et al., 2004,Lopez \& Botto, 2005; Bernardo et al., 2008).

At all tested temperatures, 1, 3, 5, 7, and 15 days of storage periods were found to be extremely important for development of $V$. canescens. Similarly, Colinet \& Boivin (2011) showed that storage period was also grave component of cold storage studies. Temperature and storage period are thought together two concepts for cold storage. For this reason dose of cold exposure can be explained by a combination of storage period and temperature (Kostal et al. 2004, 2006). With the increasing the dose of cold exposure, negative effect of cold storage enhances on natural enemies. Several studies on cold storage at different exposure times reported that survival rates of the parasitoids were reduced with exposure time (Okine et al., 1996; Langer and Hance, 2000; Pitcher et al., 2002; Colinet et al., 2006, Foerster and Doetzer, 2006; Ayvaz et al., 2008; Abd El-Gawad et al., 2010). Similarly in this study, development time and emergence ratio of $V$. canescens were significantly affected by low temperature and exposure time in both hosts. Development time increased significantly with increasing exposure time within the range of 115 days. There was no $V$. canescens development after 5-, 7- and 15-day storage at $5^{\circ} \mathrm{C}$ in both hosts and 15-day storage at $10^{\circ} \mathrm{C}$ in host $P$. interpunctella. Mortality of the parasitoids can be attributed to the ultimate cost of prolonged cold exposure. In addition to chilling injuries, parasitoids stored as immature may not have sufficient energy resources to complete their development and/or to emerge (Colinet \& Boivin 2011). Many studies reported that mortality generally increases with increasing cold storage period in both solitary and gregarious parasitoids (Langer \& Hance, 2000; Colinet et al., 2006, 2007b; Foerster \& Doetzer, 2006; Colinet \& Hance, 2010).

Nutritional resource was also important factor for biological properties of progeny in cold storage. The host represents the nutritional resource in the parasitoid (Coudron et al., 2007). In this study, cold storage of $V$. canescens was carried out on two different hosts. The host differences affected development time, longevity, progeny size/weight and emergence ratio of $V$. canescens. But longevity and weight of $V$. canescens were slightly affected by cold storage in the host $E$. kuehniella. Statistical analysis showed no significant difference in the weight of parasitoid but larger parasitoids were obtained compared to control. However, weight of $V$. canescens decreased in the host $P$. interpunctella. As describe above, this situation depends on dietary source of immature stage of parasitoid.

Liu et al., 2007 reported that variation in nutritional resource can influence low temperature tolerance by regulating low-molecular-weight sugars and polyols levels (e.g. trehalose and glycogen), body size and lipids levels. Atkinson (1994) and Anguilletta (2009) reported that insect body size increased as temperature decreases and this situation was also applied for insect parasitoid (Bazzocchi, 2003; Colinet et al., 2007a).

Cold storage studies can be divided into two main parts in parasitoid; immature stage and adult stage. In this study, cold storage of adult $V$. canescens was also tested. Storage temperature had a significant influence on the longevity of $V$. canescens in both condition and host. The highest mean longevity was obtained for $V$. canescens stored at $10^{\circ} \mathrm{C}$. If adults were fed with honey and water before, during and after storage, tolerance to low temperature significantly increased. (Shalaby \& Rabasse,1979; Ganteaume et al.,1995; Riddick, 2001; Uçkan \& Ergin, 2003).

Many studies conducted on the storage of beneficial insects indicated that emergence, lifespan and/or reproduction of cold-stored pest and beneficial insects were negatively affected (Leopold, 1998). For instance, storage of Trissolcus basalis (Wollaston) and Telenomus podisi Ashmead (Hymenoptera: 
Scelionidae) pupae at $12^{\circ} \mathrm{C}$ and $15^{\circ} \mathrm{C}$ for 4-7 moths showed different results. There was no emergence of adults at $12^{\circ} \mathrm{C}$ (Foerster et al., 2004). Gautam (1986) showed that there was no significant difference in the development of Telenomus remus Nixon (Hymenoptera: Scelionidae) stored at $10^{\circ} \mathrm{C}$ for 7 days within host eggs of Spodoptera litura (F.) (Lepidoptera: Noctuidae) when compared to control. In other study reported by Liu \& Tian (1987), Encarsia formosa Gahan (Hymenoptera: Aphelinidae) within the mummified aleyrodid host was stored at temperatures ranging from $3-12^{\circ} \mathrm{C}$ and the ratio of adult development was positively correlated with storage temperature and negatively correlated with the exposure time. When this species was stored at $<12^{\circ} \mathrm{C}$ for 20 days, there was no significant difference in the development of the parasitoid when compared to control group. The tiny parasitoid wasps, Trichogramma spp. were stored at $10^{\circ} \mathrm{C}$ for 30 days on the host Ephestia kuehniella and no adverse effect was observed on the development of parasitoid (Vigil, 1971).

All these studies confirm that storage conditions of parasitoid can vary with the species, stage, temperature and exposure time. Low temperature storage is important scientific method in mass-rearing of biological control agents. It supports flexibility and efficiency in mass production and allows to synchronize releases with appropriate host presence (Leopold, 1998). Based on our laboratory experiments, storage of $V$. canescens will permit researchers to profit flexibleness and admit of them to provide a completely biological control agent on request. The affectivity of any biological control agent utilized for insect control purpose depends on being extricated at the suitable time. We believe that the result of this study is going to provide fine data to help in the mass-rearing and timely release of $V$. canescens.

\section{Acknowledgment}

We are grateful to the Scientific and Technical Research Council of Turkey for their financial support.

\section{References}

Abd El-Gawad, H.A.A., A.M.M. Sayed \& S.A. Ahmed, 2010. Impact of cold storage temperature and period on performance of Trichogramma evanescens Westwood (Hymenoptera: Trichogrammatidae). Australian Journal of Basic and Applied Sciences, 4, 2188-2195.

Anguilletta Jr., M.J., 2009. Thermal Adaptation: A Theoretical and Empirical Synthesis. Oxford University Press, Oxford, London, $289 \mathrm{pp}$.

Atkinson, D., 1994. Temperature and organism size: a biological law for ectotherms? Advances in Ecological Research, 25: 1-58.

Ayvaz, A., E. Karasu, S. Karabörklü \& A.S. Tunçbilek, 2008. Effects of cold storage, rearing temperature, parasitoid age and irradiation on the performance of Trichogramma evanescens Westwood (Hymenoptera: Trichogrammatidae). Journal of Stored Products Research, 44: 232-240.

Ballal, C., S. Singh, S. Jalali \& P. Kumar, 1989. Cold tolerance of coccoons of Allorhogas pyralophagus [Hymenoptera: Braconidae]. BioControl, 34: 463-468.

Barke, J., I. MateoLeach \& L.W. Beukeboom, 2005. Fitness of arrhenotokous and thelytokous Venturia canescens. Proceedings of the Section Experimental and Applied Entomology of the Netherlands Entomological Society NEV Amsterdam, 16:27-35.

Bazzocchi, G.G., A. Lanzoni, G. Burgio \& M.R. Fiacconi, 2003. Effects of temperature and host on the pre-imaginal development of the parasitoid Diglyphus isaea (Hymenoptera: Eulophidae). Biological Control, 26: 74-82.

Belingl, 1932. Zur Biologie von Nemeritis canescens Grav (HymenOphion). Zeitschrift Fur Angewandte Entomologie, 19:223-249.

Bernardo, U., L. lodice, R. Sasso \& P.A. Pedata, 2008. Effects of cold storage on Thripobius javae (=T. semiluteus) (Hymenoptera: Eulophidae). Biocontrol Science and Technology, 18: 921-933.

Beukeboom, L. W. \& L.P. Pijnacker, 2000. Automicticparthenogenesis in the parasitoid Venturia canescens (Hymenoptera: Ichneumonidae) revisited. Genome, 43:939-944. 
Beukeboom, L.W., G. Driessen, L. Luckerhoff, C. Berstein, L. Lapchin, \& J.J.M. vanAlphen, 1999. Distribution and Relatedness of sexual and asexual Venturia canescens (Hymenoptera). Proc. VIIlth Meeting Exp. Appl. Entomol. Neth. 10:23-28.

Bigler, F. 1994. Quality control in Trichogramma production in Biological Control with Eggs Parasitoids CAB International, (Eds Wajnberg, E. \& S.A. Hassan), Wallingford, UK, pp, 93-111.

Bonsall, M.B. \& M.P. Hassell, 1998. Population dynamics of apparent competition in a host-parasitoid assemblage. Journal of Animal Ecology, 67: 918-929.

Boz, A. \& A. Gülel, 2012. Ephestia kuehniella Zeller (Lepidoptera: Pyralidae) larvalarının hemolenfindeki toplam protein, lipit ve karbonhidrat miktarlarına parazitlenme sonrası geçen süre ve sıcaklığın etkisi. Türkiye Entomoloji Dergisi, 36: 239-247.

Boz, A. 2006. Parazitoit Venturia canescens (Gravenhorst) (Hymenoptera: Ichneumonidae)' le Parazitlenen, Konukçu Ephestia kuehniella (Zeller) (Lepidoptera: Pyralidae) Larvalarının Hemolenfindeki Toplam Protein Lipit ve Karbohidrat Miktarı Üzerine Parazitlenme Sonrası Geçen Süre ve Sıcaklığın Etkileri, On Dokuz Mayıs Üniversitesi, Fen Bilimleri Enstitüsü, Yüksek Lisans Tezi, Samsun, $48 \mathrm{~s}$.

Bulut, H \& N. Kılınçer, 1987. Yumurta parazitoiti Trichogramma spp. (Hym: Trichogrammatidae) un güvesi (Ephestia kuehniella Zell.) (Lepidoptera: Pyralidae) yumurta üretimi ve konukçu parazitoid ilişkileri. Türkiye 1. Entomoloji Kongresi Bildirileri, İzmir, s.13-16.

Cline, L.D., , B.R. Flaherty \& J.W. Press, 1983. Response of parasitoids and predators of stored-product insects to whitelight or blacklight traps. Journal of Economic Entomology, 76: 298-301.

Colinet, H., D. Renault, T. Hance \& P. Vernon, 2006. The impact of fluctuating thermal regimes on the survival of a cold-exposed parasitic wasp, Aphidius colemani. Physiological Entomology, 31: 234-240.

Colinet, H., G. Boivin \& T. Hance, 2007a. Manipulation of parasitoid size using the temperature-size rule: fitness consequences. Oecologia, 152: 425-433.

Colinet, H., P. Vernon \& T. Hance, 2007b. Does thermal-related plasticity in size and fat reserves influence supercooling abilities and cold-tolerance in Aphidius colemani (Hymenoptera: Aphidiinae) mummies? Journal of Thermal Biology, 32: 374-382.

Colinet, H. \& T. Hance, 2010. Interspecific variation in the response to low temperature storage in different aphid parasitoids. Annals of Applied Biology, 156: 147-156.

Colinet, H. \& G. Boivin, 2011. Insect parasitoids cold storage: A comprehensive review of factors of variability and consequences. Biological Control, 58: 83-95.

Driessen, G., Bernstein, C., van Alphen, J.J.M. \& Kacelnik, A. 1995. A count down mechanism for host search in the parasitoid Venturia canescens. Journal of Animal Ecology, 64: 117-125.

Foerster, L.A. \& A.K Doetzer, 2006. Cold storage of the egg parasitoids Trissolcus basalis (Wollaston) and Telenomus podisi Ashmead (Hymenoptera: Scelionidae). Biological Control, 36: 232-237.

Freeman, P. 1980. Common Insect Pests of Stored Food Products. 6nd edn. Economic Series London. British Museum (Natural History), London.

Frilli, F. 1965. Studi sugli imenotteri ichneumonidi. I. Devorgilla canescens (Grav.). Entomologica, 1: 119-209.

Gade, B. \& E.D.Jr. Parker, 1997.The effect of life cycle stage genotype on dessication tolerance in the colonizing parthenogenetic cockroach Pycnoscelus surinamensis anditsancestor $P$. indicus. Journal of Evolutionary Biology. 10: 479-491.

Ganteaume, A., E. Tabone \& N. Poinsot-Balaguer, 1995. Variation du potentiel biotique de l'auxiliaire parasite Encarsia formosa (Hymenoptera: Aphelinidae) en fonction du stockage au froid 2. Du point de vue de la fécondité journalière et de la longévité. Journal of Applied Entomology, 119: 547-551.

Gautam, R. D., 1986. Effect of cold storage on the adult parasitoid Telenomus remus Nixon (Scelionidae: Hymenoptera) and the parasitized eggs of Spodoptera litura (Fabr.) (Noctuidae: Lepidoptera). J. Entomol. Res. 10: 125-131.

Glenister, C. S. \& M. P. Hoffmann, 1998. Mass-reared natural enemies: Scientific, technological, and informational needs and considerations,. In Mass-reared natural enemies: application, regulation, and needs. (Eds R. Ridgway, M. P. Hoffmann, M. N. Inscoe \& C. S. Glenister ), Proceedings: Thomas Say Publications in Entomology. Entomological Society of America, Lanham, MD. pp. 242-247 
Goater, B. 1986. British Pyralid Moths - a Guide to Their Identification. Harley Books, Colchester, UK.

Gökçek, N., 2005. Farklı Besin Ortamlarında Yetiştirilen Değişik Konukçularda Koinobiont Parazitoit Venturia canescens (Hym: Icneumonidae)' nin Gelişimi. Ankara Üniversitesi Fen Bilimleri Enstitüsü, Yüksek Lisans Tezi, Ankara,s.80.

Harvey, J.A., I.F. Harvey \& D.J. Thomson, 1993. The effect of superparasitism on development of the solitary parasitoid wasp, Venturia canescens (Hymenoptera: Ichneumonidae). Ecological Entomology, 18: 203-208.

Harvey, J.A. \& D.J. Thompson, 1995. Developmental interactions between the solitary endoparasitoid Venturia canescens (Hymenoptera: Ichneumonidae), and two of its hosts, Plodia interpuctella and Corcyra cephalonica (Lepidoptera: Pyralidae). European Journal of Entomology, 92: 427-435.

Harvey, J.A. \& L.E.M. Vet, 1997. Venturia canescens parasitizing Galleria mellonella and Anagasta kuehniella: differing suitability of two hosts with highly variable growth potential. Entomologia Experimentalis Et Applicata, 84: 93-96.

Jokela, J., C.M. Lively, M.F. Dybdahl \& J.A. Fox, 1997. Evidence for a cost of sex in the fresh watersnail Potamopygus antipodarum. Ecology, 78: 452-460.

Kansu, İ. A. \& A. Uğur, 1985. Venturia canescens (Grav.) (Hym.; Ichnenumonidae)'in yetiştirilmesinde uygun asalak :konukçu oranı ile birlikte tutulma süresinin belirlenmesi üzerinde bir araştırma. Doğa Bilim Dergisi, 10: 80-83.

Kostal, V., J. Vambera \& J. Bastl, 2004. On the nature of pre-freeze mortality in insects: water balance, ion homeostasis and energy charge in the adults of Pyrrhocoris apterus. Journal of Experimental Biology 207: 1509-1521.

Kostal, V., M. Yanagimoto \& J. Bastl, 2006. Chilling-injury and disturbance of ion homeostasis in the coxal muscle of the tropical cockroach (Nauphoeta cinerea). Comparative Biochemistry and Physiology A: Molecular and IntegrativePhysiology, 143, 171-179.

Langer, A., \& T. Hance, 2000. Overwintering strategies and cold hardiness of two aphid parasitoid species (Hymenoptera: Braconidae: Aphidiinae). Journal of Insect Physiology, 46: 671-676.

Leopold, R .A., 1998. Cold storage of insects for integrated pest management. In:, Temperature Sensitivity in Insects and Application in Integrated Pest Management. (Eds Hallman, G.J. \& D.L.Denlinger), Westview Press, Boulder, pp. 235-267.

Leopold, R.A., R.R. Rojas \& P.W. Atkinson, 1998. Post pupariation cold storage of three species of flies: increasing chilling tolerance by acclimation and recurrent recovery periods. Cryobiology 36: 213-224.

Liu, J. J. \& Y. Tian, 1987. Cold storage of Encarsia formosa Gahen. Chinese Journal of Biological Control, 3: 4-6.

Liu, Z., P. Gong, K. Wu, W. Wei, J. Sun \& D. Li, 2007. Effects of larval host plants on over-wintering preparedness and survival of the cotton bollworm, Helicoverpa armigera (Hübner) (Lepidoptera: Noctuidae). Journal of Insect Physiology, 53: 1016-1026.

Lopez, S.N. \& E. Botto, 2005. Effect of cold storage on some biological parameters of Eretmocerus corni and Encarsia formosa (Hymenoptera: Aphelinidae). Biological Control, 33: 123-130.

McKenzie, J.D. \& R. Goldman, 2005. The student guide to MINITAB Release 14 Manual. Boston: Pearson Education, Inc.

McDonald, R.C. \& L. T. Kok, 1990. Post refrigeration viability of Pteromalus puparum (Hymenoptera: Pteromalidae) prepupae within host chrysalids. Journal of Entomological Science, 25: 409-413.

Okine, J.S., E.R. Mitchell, \& G.Y. Hu, 1996. Low temperature effect on viability of Diadegma insulare (Hymenoptera: Ichneumonidae) pupae and effect of this parasitoid on feeding rate of Diamondback Moth Larvae (Lepidoptera: Plutellidae). Florida Entomologist, 79: 503-509.

Ozkan, C., 2007. Effect of food, light and host instar on the egg load of the synovigenic endoparasitoid Venturia canescens (Hymenoptera: Ichneumonidae) Journal of Pest Science, 80:79-83.

Özkan, C. \& M.O. Gürkan, 2002. Konukçu yaşının soliter koinobiont endoparazitoid olan Venturia canescens (Grav.) (Hymenoptera: Ichneumonidae)'in bazı biyolojik özellikleri üzerine etkileri. Türkiye Entomoloji Dergisi, 26:83-91.

Özkan, C., 1999. Venturia canescens (Grav) (Hymenoptera: Ichnenumonidae) ile Ephestia kuehniella (Lepidoptera: Pyralidae) arasındaki bazı biyolojik ilişkiler üzerine arastırmalar. Ankara Üniversitesi Fen Bilimleri Enstitüsü Bitki Koruma Bölümü Doktora Tezi, Ankara, $97 \mathrm{~s}$. 
Özkan, C., 2004. İki farklı konukçu dönemi üzerinde yetiştirilen endoparazitoid Venturia canescens (Grav.) (Hymenoptera: Ichneumonidae)'in yaşam süresine farklı ışıklanma süresinin ve farklı besinin etkileri. A.Ü.Z.F. Tarım Bilimleri Dergisi, 3: 313-317.

Özkan, C.,2006. Laboratory rearing of the solitary egg-larval parasitoid, Chelonus oculator Panzer (Hymenoptera: Braconidae) on a newly recorded factitious host Plodia interpunctella (Hübner) (Lepidoptera: Pyralidae) Journal of Pest Science, 79: 27-29.

Özkan, C., N. Gökçek \& H. Tunca, 2003. Development time, fecundity and longevity of Venturia canescens (Gravenhost) (Hymenoptera: Ichneumonidae) with Ephestia kuehniella Zeller (Lepidoptera: Pyralidae) as host. Integrated Protection of Stored Products. IOBC Bulletion/ WPRS, 27 :173-175.

Pitcher, S.A., M.P. Hoffmann, J. Gardner, M.G. Wright \& T.P. Kuhar, 2002. Cold storage of Trichogramma ostriniae reared on Sitotroga cerealella eggs. BioControl, 47: 525-535.

Press, J. W. \& R. T. Arbogast, 1991. Effect of low temperature on survival of ımmatures of the parasite Venturia canescens (Gravenhorst) (Hymenoptera: Ichneumonidae). Journal of the Kansas Entomological Society, 64: 345-348

Press, J.M., L.D. Cline \& B.R. Flaherty, 1982. Acomparison of two parasitoids, Bracon hebetor (Hymenoptera: Braconidae) and Venturia canescens (Hymenoptera: Ichneumonidae), and a predator Xylocoris flavipes (Hemiptera: Anthocoridae) in suppressing residual populations of the almond moth, Ephestia cautella (Lepidoptera: Pyralidae). Journal of the Kansas Entomological Society, 90: 725-728.

Riddick, E.W., 2001. Effect of cold storage on emergence, longevity, fertility, andsurvival of Cotesia marginiventris (Hymenoptera: Braconidae). Journal of Entomological Science, 36: 366-379.

Rogers, D., 1972. The ichneumon wasp Venturia canescens: Oviposition and avoidance of superparasitsm. Entomologia Experimentalis et Applicata, 15: 190-194.

Rundle, B.J., L. J. Thomson, \& A.A. Hoffmann, 2004. Effects of cold storage on field and laboratory performance of Trichogramma carverae (Hymenoptera: Trichogrammatidae) and the response of three Trichogramma spp. ( $T$. carverae, T. nr. brassicae, and T. funiculatum) to cold. Journal of Economic Entomology, 97: 213-221.

Sahin, A. K. \& C., Ozkan, 2007. Effect of light on the longevity and fecundity of Venturia canescens (Gravenhorst) (Hymenoptera:Ichneumonidae). Pakistan Journal of Zoology, 39: 315-319.

Salt, G. 1975. The fate of an internal parasitoid, Nemeritis canescens, in a variety of insects. Transactions of the Royal Entomological Society of London, 127: 141-161.

Salt, G., 1976. The host of Nemeritis canescens a problem in the host specificity on Insect parasitoids. Ecological Entomology, 1: 63-67.

Schneider, M.V., L.W. Beukeboom, G. Driessen, L. Lapchin, C. Bernstein \& J.J.M. van Alphen, 2002. Geographical distribution and genetic relatedness of sympatrical thelytokous and arrhenotokous populations of the parasitoid Venturia canescens (Hymenoptera). Journal of Evolutionary Biology, 15: 191-200.

Shalaby, F.F. \& J.M. Rabasse, 1979. Effect of conservation of the aphid parasitoid Aphidius matricariae Haliday (Hymenoptera: Aphidiidae) on adult longevity, mortality and emergence. Annals of Agricultural Science, 11: 58-71.

Uçkan, F. \& E. Ergin, 2003. Temperature and food source effects on adult longevity of Apanteles galleriae Wilkinson (Hymenoptera: Braconidae). Environmental Entomology, 32: 441-446.

van Lenteren, J. \& M. Tommasini, 2002. Mass production, storage, shipment and quality control of natural enemies. In: Mass Production, Storage, Shipment and Quality Control of Natural Enemies, Integrated Pest and Disease Management in Greenhouse Crops. (Eds R. Albajes, M.L. Gullino, J.C. van Lenteren \& Y. Elad), Springer, Netherlands, pp. 276-294.

Venkatesan, T., S.P. Singh \& S.K. Jalali, 2000. Effect of cold storage on cocoons of Goniozus nephantidis Muesebeck (Hymenoptera: Bethylidae) stored for varying periods at different temperature regimes. Journal of Entomological Research, 24: 43-47.

Vigil, B. O. 1971. Laboratory multiplication and release of Trichogramma sp. with a view to controlling Heliothis zea (Boddie) and Alabama argillacea (Hb.) in EISalvador (Central America). Coton Fibres Tropicales, 26: 211-216.

Vrijenhoek.1999. Parthenogens and natura Iclones. Encyclopedia Reproduction, 3: 695-702. 
